Masthead Logo

Criticism

Volume $61 \mid$ Issue 1

Article 7

\title{
The Other Terror: Remembering the Paris Commune
}

Elizabeth Duquette

Gettysburg College

Follow this and additional works at: https://digitalcommons.wayne.edu/criticism

\section{Recommended Citation}

Duquette, Elizabeth () "The Other Terror: Remembering the Paris Commune," Criticism: Vol. 61 : Iss. 1 , Article 7. Available at: https://digitalcommons.wayne.edu/criticism/vol61/iss1/7 
THE OTHER

TERROR:

REMEMBERING

THE PARIS

COMMUNE

Elizabeth Duquette

Sensational Internationalism: The

Paris Commune and the Remapping of American Memory in the Long Nineteenth Century by J. Michelle Coghlan. 232 pp. Edinburgh:

Edinburgh University Press, 2016. Hardback 75£; Paperback 19.99£
In late May 1871, the eyes of the world turned, again, to Paris. The bloody end of the Commune, the government established in the wake of the Second Empire's collapse, horrified even those who supported the action. Across its nearly sixty day control of the city, the Commune worked to institute a radical agenda, separating church and state, providing protections for workers, and introducing provisions for greater gender equity. J. Michelle Coghlan's Sensational Internationalism: The Paris Commune and the Remapping of American Memory in the Long Nineteenth Century recovers the event's “spectacular afterlife," pointing to its surprising durability in the US imagination (3). Assembling an archive that includes poems and illustrations, a bestselling novel about a werewolf and the late fiction of Henry James, newspaper articles and pyrodramas, Coghlan demonstrates how the Commune emerged, and re-emerged, in "print and visual media" across "five decades" (6).

Coghlan's book traces two distinct threads in the Commune's long American afterlife- one conservative, the other radical—although the book's organization is loosely chronological. The first two chapters detail how writers deployed the Commune in postbellum debates about gender, considering the role of the pétroleuse (female incendiaries) in policing radical female identity and exploring Paris as a 
setting for late-century adventure narratives as well as the "imperial" masculinity thus offered to American men; in both instances, the Commune represented a threat to social order. But it is the Commune's ongoing importance to radical discourse that is the book's main interest. Turning to anniversary celebrations across the turn of the century, as well as novels from the 1930s, Coghlan reconstructs the Commune's ongoing influence. "To celebrate the Commune in the late nineteenth- and early twentiethcentury US was," she writes, "to live by and through a radical calendar whose sense of alternate time and subversive affiliation provided the grounds for extra-national feeling as an embodied practice of radical memory-making: internationalism as at once temporality and sensation" (84). Sandwiched between the chapters on radical politics is a reading of Henry James's Paris, with particular attention to the "burned palace," "a remarkably densely coded site of historical memory" in The Ambassadors (125). James is no radical, of course, but Coghlan's reading of the Commune's appeal to his senses_- "Beneath all this neatness and coquetry, you seem to smell the Commune suppressed, but seething"- unfolds the complexities of his historical (and, to a lesser extent, political) sense (118).

With the notable exception of James and, to a lesser extent, Sarah Piatt, most of the materials
Coghlan surveys have faded from critical view. One of the book's chief strengths is thus the multifaceted and rich archive it (re) constructs. This is particularly evident in Coghlan's attention to Lucy Parsons, a Black radical thinker whose "sixty-year career as an activist, orator, journalist, and Haymarket archivist has ... received scant scholarly attention" (93). Pulling Parsons out of the shadow cast by her husband, Haymarket martyr Albert Parsons, is difficult because, despite her numerous public appearances, "we have not a single full transcript of her speeches ... nor an extant authorized published essay version of what she said" (93). Juxtaposing a work Parsons did publish-The Life of Albert Parsons (1889) — with her "spectacular ongoing presence in mainstream US newspapers" (94), Coghlan deftly capture a sense of "the exhilaration she provoked in radical audiences," as well as "the trepidation she unleashed" for readers with differing political orientations (94). This careful archival work simultaneously establishes connections between the events of the Commune and US "struggles of the 1870s and 1880s" (100) and unearths "a counter-archive of radical memory" that includes figures like Parsons herself (97).

This is a useful and timely book, even if it does not fully deliver on the ambitious claims proposed in its introduction. Sensational 
Internationalism gathers an impressive collection of US materials about the Commune, and the book is invaluable in its attention to the radical politics of the latenineteenth and early-twentieth centuries. When it strays from its archival emphasis, as in the chapter on James or during its more theoretical moments, its footing is less sure. That the Commune participates in a long history of US fascination with French political violence, most notably the Terror, falls outside the scope of the study; nevertheless, this longer history complicates the readings offered in Sensational Internationalism, particularly those concerning the structures of "transatlantic feeling" (5). Its most inexplicable lapse, however, is the absence of the Commune itself. Since the premise of Sensational Internationalism derives from the apt observation that the Commune has been largely overlooked_- "oftwritten about and oft-forgotten" (9) — it is odd that no overview of the event is included to orient readers, given that Coghlan begins by observing "just how much we have forgotten about how radically transatlantic the experience of the Commune was" (2). As she rightly notes, however, the Commune "seems curiously new" and Sensational Internationalism helps us to see the many reasons we were wrong to have forgotten it in the first place (1).

Elizabeth Duquette is professor of English at Gettysburg College. Her books include Loyal Subjects: Bonds of Nation, Race, and Allegiance in Nineteenth-Century America; Elizabeth Stuart Phelps: Selected Tales, Essays, and Poems (with Cheryl Tevlin); and The Gates Ajar (with Claudia Stokes). She is currently finishing America's Napoleon Complex: Tyranny and Ubiquity across the Nineteenth Century. With Stacey Margolis, she edits J19: The Journal of Nineteenth-Century Americanists. 
